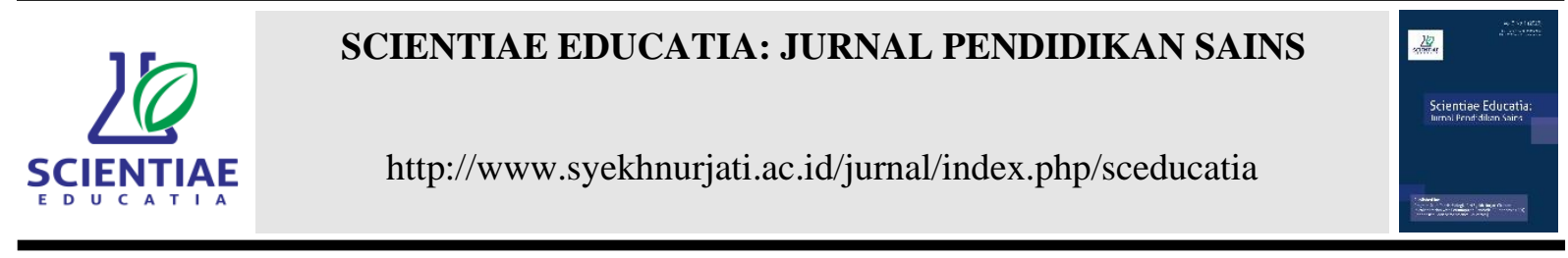

\title{
Profile of Students' Reasoning Levels Using Ranking Task Exercises in Physics Learning
}

\author{
St. Syamsudduha ${ }^{\mathrm{a}}$, Fitriani ${ }^{\mathrm{b}^{*}}$, Suhardiman ${ }^{\mathrm{b}}$ \\ ${ }^{a}$ Department of Islamic Education Management, Faculty of Tarbiyah and Teacher Training, UIN Alauddin Makasar, \\ South Sulawesi, Indonesia \\ ${ }^{\mathrm{b}}$ Department of Physics Education, Faculty of Tarbiyah and Teacher Training, UIN Alauddin Makasar, South \\ Sulawesi, Indonesia
}

${ }^{*}$ Corresponding author: Sultan Alauddin Street, Romangpolong, Somba Opu, Gowa, Soult Sulawesi, 92113, Indonesia. E-mail address: fitrianif454@gmail.com

\section{a r t i c 1 e i n f o}

Article history:

Received: 19 October 2021

Received in revised form: 13

November 2021

Accepted: 24 December 2021

Available online: 30 December 2021

Keywords:

Level of reasoning

Physics learning

Ranking task exercise

\section{a b s t r a c t}

This research aimed to find out the reasoning level profile of students by using Ranking Task Exercise questions in the physics learning material for Work and Energy for class X MIPA at SMAN 24 Bone. The dependent variable in this study is the level of students' reasoning with this type of quantitative descriptive research. The subjects of this study were students of class X MIPA SMAN 24 Bone, totaling 49 people. The research instrument used was a question in a Ranking Task Exercise of ten numbers. Based on the research results, students' most common level of reasoning is the second level of reasoning category, namely subfunctional as many as 24 people with a percentage of $49 \%$. The cause of the reasoning level of most students in the subfunctional category is that students still feel unfamiliar with questions in the form of the Ranking Task Exercise, so they have difficulty answering questions. In addition, the distance between giving material and giving questions is far enough that students have forgotten the concept of Work and Energy material. From this study, it can be concluded that the level of reasoning of students is still low. The order of the students' reasoning starts from the most to the least, namely subfunctional, unstructured/alternative, near functional, functional, and expert. This research implies that after the results of this research are obtained, it can be said that by knowing the level profile of students' reasoning in learning physics, it is expected to be an evaluation material for educators to apply an approach that can train students' scientific reasoning in learning physics. 2021 Scientiae Educatia: Jurnal Pendidikan Sains

\section{Introduction}

Education is one of the fields offered by the community to prepare the workforce of future generations. Therefore, the purpose of education must meet the demands of a constantly changing world (Bao \& Koenig, 2019). Education has an important role, so it is necessary to play an active role in improving the quality and quantity of students' thinking patterns. Improving students' thinking patterns needs to be supported through the right learning process so that students' abilities or skills can develop properly (Rahmawati, 2018). One of the characteristics of 21st-century skills is that it demands human resources who can think and reason scientifically to 
solve various kinds of problems (Handayani et al., 2020; Zulfaidhah et al., 2018). Problemsolving skills are basic human cognitive processes (Md, 2019).

Reasoning is one of the 21st-century skills that is expected to be taught in the classroom to prepare students to be successful in facing the challenges of globalization. This reasoning ability can be defined as "a complex construct, which includes the skills required for scientific problem solving, generic cognitive abilities, such as the use of analogies and decision making, and the ability to apply content, procedural, and epistemic knowledge to problem-solving (Göhner \& Krell, 2020; Krell et al., 2018).

Keraf explains reasoning (a way of thinking or reasoning) as "a thought process that seeks to connect known facts or evidence or evidence to a conclusion"(Krell et al., 2021; Utami et al., 2014). In addition, Sadiq defines reasoning as an activity, process, or thought activity to arrive at a conclusion or make a new statement that is true based on statements that have been previously proven or assumed (Shodiq, 2004). Reasoning skills consist of several sub-skills, such as formulating hypotheses, planning investigations, and analyzing and interpreting data (Krell et al., 2020; Mahler et al., 2021).

Physics learning in high school requires students to be able to explore information with full reasoning, understand concepts, conduct evaluations, be open, be able to solve problems, and make decisions. Thus, the physics learning process needs to be in line with the nature of physics learning and must refer to content standards and graduate competency standards (Cavallo et al., 2002).

Based on data from the Organization for Economic Co-Operation and Development (OECD), test results based on the Program for International Student Assessment (PISA) from 2006 to 2015 showed that the average ranking of Indonesian students was in the fifth-lowest rank, although in 2015 it was seen from the score the median obtained showed an increase of 17 points, namely from 318 to 335 (Nizam, 2016; OECD, 2016). In 2009 it showed that students' low scientific reasoning ability in Indonesia was ranked 60th out of 65 countries and had a score of 385 . This figure is relatively low compared to the average score applied by the OECD, which is a score of 501, especially on the science scale (Purwana et al., 2016). This proves that the learning process has not yet developed the ability to think logically (Burais et al., 2020).

Physics-based reasoning learning stimulates students' mental and physical activities to acquire scientific knowledge. By studying physics, students are expected to reason and think logically, analytically, critically, and creatively (Palloan \& Swandi, 2019). Students should know the content of physics in the form of facts, concepts, or principles and be able to investigate, collect evidence, analyze, and assess students' understanding of physics (Erlina et al., 2018). Several studies have shown that students with low reasoning abilities tend to have a low conceptual understanding. When students understand a concept, it will be easier for them to describe the concept in their language, and this also requires reasoning skills in thinking as well (Abdurrahman \& Efendi, 2013; Nguyen \& Rebello, 2011). Students' conceptual understanding can grow through the ability to think logically (Akmam et al., 2018).

The process of learning physics in high school requires an assessment that can measure the level of reasoning of students. The test that can be used is in the form of a Ranking Task (RT). Ranking Task Exercise has several advantages; namely, RTE is a conceptual exercise that can be used as a learning model as well as a tool to assess students' level of reasoning; explore more areas of abilities and skills so that they can train and build more flexible thinking patterns of students (Shen et al., 2020; A. F. C. Wijaya \& Ramalis, 2012).

The form of the Ranking Task question as a test tool has four basic components, namely a description of the situation including how to sort it; show several pictures with different 
conditions for comparison; a place to sort the pictures in each situation or state the same for each situation; and a place to explain the reasons why answer like that (Syafaat et al., 2014).

"By rating then giving reasons, students are encouraged to do more than just rote answers" (Hudgins, 2007). In addition, the Ranking Task Exercise (RTE) can develop students' natural ideas, especially on the concept of physics. To be more persuasive, O'kuma et al. added an element at the bottom that identified the students' beliefs about answers. A quote from O'Kuma (2004) "Ranking tasks are useful in a variety of ways. They make good homework assignments and good test questions". Thus, the Ranking Task as a conceptual exercise can be used to measure student learning achievement. In addition, Ranking Tasks can also strengthen students' understanding of physics concepts (O'Kuma et al., 2004). By giving a question in the form of Ranking Task, Exercise Students are expected to be able to practice and develop thinking patterns, especially the ability to reason by working on complex problems.

\section{Method}

This type of research is descriptive quantitative research. This study aims to describe and describe existing phenomena, both natural and human-engineered phenomena, and this study examines activity patterns, characteristics, changes, relationships, similarities, and differences with other phenomena. In quantitative descriptive research, the description or description uses size, quantity, or frequency (Sukmadinata, 2014). This research was conducted at SMAN 24 Bone, located at Jalan Poros Bone-Wajo, Pattiro, Dua Boccoe District, Bone Regency, South Sulawesi. The subjects in this study were all students of class X MIPA SMAN 24 Bone which consisted of three classes with a total of 49 students.

The instrument used in this research is a question sheet in the form of physics questions in a Ranking Task Exercise that students will complete. This instrument is used to determine the level of reasoning of students in learning physics with the material of effort and energy that looks at indicators or rubrics for assessing the level of reasoning per question.

Before using the research instrument, it is necessary to validate the instrument. Validity is a measure of how effective and strong an instrument is. An instrument can be valid if it can measure what is desired and can reveal data about students' problem-solving abilities. The high and low validity of the instrument shows how the data collected does not deviate from the description of the indicators of reasoning ability. The instruments used in this study will be validated by two experts (expert validation or expert validation). The instrument is considered valid if validators 1 and 2 provide an average value of 3 and 4 . The level of instrument validity is tested using the Aiken V indicator (Retnawati, 2006).

$$
V=\frac{\sum s}{n(c-1)}
$$

Description: V: index of rater agreement on item validity; s: index of rater agreement on item validity $(\mathrm{s}=\mathrm{r}-1$, with $\mathrm{r}=$ rater choice category score and lo the lowest score in the scoring category); n: number of raters; $c$ : the number of categories that the rater can choose

Tabel 1. Instrument validity criteria

\begin{tabular}{cc}
\hline Score Range $(\mathbf{V})$ & Validity Level \\
\hline $\mathrm{V}<0,4$ & Low validation \\
$0,4 \leq \mathrm{V} \geq 0,8$ & Medium validation \\
$\mathrm{V}>0,8$ & High validation \\
\hline & (Retnawati, 2006)
\end{tabular}


Descriptive analysis was used to describe the scores of all variables in this study. In this technique, the data presentation is in the form of 1) determining the level of reasoning of students seen from the answers in the Ranking Task Exercise based on the rubric of the level of reasoning. 2) make a table of the students' reasoning level for each question, 3) determine the mode of the students' reasoning level seen from the whole question, 4) determine the percentage of the students' reasoning level, and 5) Present the students' reasoning level data in a bar chart. The following is the rubric for the level of reasoning students used:

Table 1. Reasoning Level Rubric of Learners

\begin{tabular}{ll}
\hline \multicolumn{1}{c}{ Reasoning Level } & \multicolumn{1}{c}{ Indicator } \\
\hline Level 5: Expert & $\begin{array}{l}\text { Complex and accurate, students can express all relevant concepts. This } \\
\text { includes naming the important variables and accurately describing the nature } \\
\text { of these variables and the rules that relate them to the observed phenomena. } \\
\text { The general process can be clearly expressed in appropriate scientific } \\
\text { language. } \\
\text { Level 4: Functional } \\
\text { Solutions to problems can be precisely presented, but shorter (generally } \\
\text { correct) descriptions outline the variables and interactions. It can also be } \\
\text { supplemented with a general description of the process. } \\
\text { The learner's description includes the identification of two or more variables } \\
\text { and the relationship of related concepts but does not reveal one or more } \\
\text { Functional } \\
\text { knowledge of the important elements. The explanations are sometimes } \\
\text { confusing in language representation or context but usually provide the correct } \\
\text { solution. However, student descriptions show limited conceptual } \\
\text { understanding and do not have sufficient depth or flexibility to explain } \\
\text { whether the same concept results from minor changes in presentation or } \\
\text { presents another conceptual problem. } \\
\text { Students' explanations can correctly identify at least one relevant variable, but } \\
\text { only the component concepts are revealed. Students did not explain the } \\
\text { relationships between core variables, and student descriptions often contained } \\
\text { significant language errors, contradictions, or logical simplifications. } \\
\text { Students can identify a related variable, but they cannot describe or display it } \\
\text { when they recognize the components of the concept. Or, students describe } \\
\text { alternative models that are not based on scientific studies. }\end{array}$ \\
\hline
\end{tabular}

(Hudgins, 2005)

\section{Result and Discussion}

This type of quantitative descriptive research will provide an overview of the level profile of students' reasoning after being given a question in the form of a Ranking Task Exercise. The researcher gave 10 number questions with the material of work and energy to the students of class X MIPA at SMAN 24 Bone.

After the Ranking Task Exercise questions were distributed to students, the researcher then examined the answers that had been given so that they could be analyzed to determine the level of students' reasoning from the five levels of reasoning according to Hudgins, namely Expert, Functional, Near functional, Subfunctional, and Unstructured/Alternative. The following is the result of the researcher's analysis of each number of questions done by 49 students of class $\mathrm{X}$ MIPA SMAN 24 Bone. An overview of students' answers at each level of reasoning with fulfilled indicators, namely: 
Table 3. Overview of students' answers

\begin{tabular}{|c|}
\hline Student Answers \\
\hline 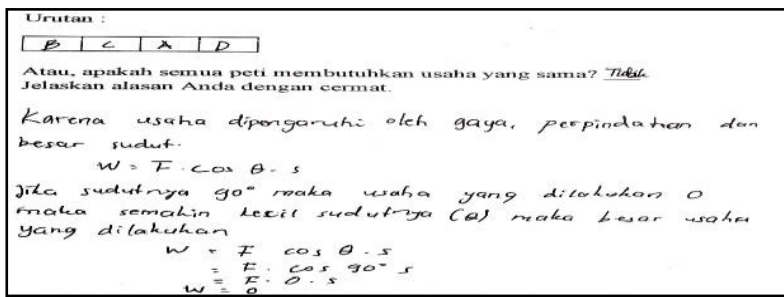 \\
\hline
\end{tabular}

The students' answers can be categorized as expert reasoning level because the answers given by students are in accordance with the expert reasoning level indicators in the assessment rubric. In students' answers, the explanation given is complete and accurate, can describe the relationship between variables based on the images presented, and the appropriate solutions.

\section{Urutan:}

\begin{tabular}{|l|l|l|l|}
\hline$D$ & $C$ & $A$ & $B$ \\
\hline
\end{tabular}

Ataui, apakah semua massa keempat bola sama besar?

Jelaskan alasan Anda dengan cermat.

Karena, Semakin besar massa bola tersebut maka semakin besar Pula usaha jang ditimbulkan bola tersebut.

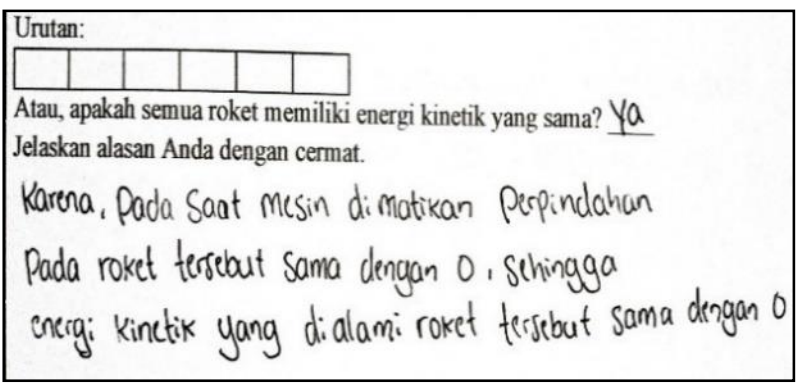

Urutan :

\begin{tabular}{|l|l|l|l|}
\hline$D$ & $A$ & $C$ & $B$ \\
\hline
\end{tabular}

Atau, apakah semua peti membutuhkan usaha yang sama? Jelaskan alasan Anda dengan cermat.

Karena, semakin besar gaya yang ditimbulkan naka semakin besar Pula massa yang di butunkan.
The answer on the side is included in the category of functional reasoning level. Students can reveal the core variables of the questions and can describe the relationship between variables. The explanations given by students are brief, but in general, the solutions are correct.

The answer on the side is included in the category of the near-functional level of reasoning. From the students' answers above, they were able to identify two variables, but they were still not quite right. The explanation is given by students still does not follow the description of the problem, but it still produces the correct solution.

The students' answers above are included in the subfunctional reasoning category. Students have identified two variables but did not identify the core variables asked from the questions. The relationship between variables is still unclear and contains misapplications in the language.

The students' answers are included in the Unstructured/alternative category. Students only correctly identified one variable from the four variables contained in the questions. Students cannot describe the relationship between variables and only repeat the instructions from the questions. 
Based on the analysis of students' answers after working on the Ranking Task Exercise, the data on the percentage of students' level of reasoning from each question can be seen in the table below.

Table 4. Percentage of reasoning level of personal learners

\begin{tabular}{cccccc}
\hline Question & \multicolumn{5}{c}{ The percentage level of reasoning } \\
\cline { 2 - 6 } number & Expert & Functional & Nearfunctional & Subfunctional & Unstructured \\
\hline 1 & $6 \%$ & $6 \%$ & $8 \%$ & $61 \%$ & $18 \%$ \\
2 & $0 \%$ & $12 \%$ & $4 \%$ & $47 \%$ & $37 \%$ \\
3 & $4 \%$ & $2 \%$ & $12 \%$ & $57 \%$ & $24 \%$ \\
4 & $0 \%$ & $4 \%$ & $16 \%$ & $39 \%$ & $41 \%$ \\
5 & $0 \%$ & $0 \%$ & $14 \%$ & $39 \%$ & $47 \%$ \\
6 & $0 \%$ & $0 \%$ & $8 \%$ & $45 \%$ & $47 \%$ \\
7 & $0 \%$ & $4 \%$ & $14 \%$ & $37 \%$ & $45 \%$ \\
8 & $0 \%$ & $4 \%$ & $4 \%$ & $47 \%$ & $45 \%$ \\
9 & $0 \%$ & $0 \%$ & $10 \%$ & $37 \%$ & $53 \%$ \\
10 & $2 \%$ & $0 \%$ & $6 \%$ & $37 \%$ & $55 \%$ \\
\hline
\end{tabular}

Based on the table above, when viewed from the overall answers of students, most of the students are only in the sub-functional and unstructured categories, only a small part is in the near-functional category, and only very few can reach the functional and expert categories. The number of students included in the level of Expert, Functional, Nearfunctional, Subfunctional, and Unstructured/Alternative reasoning can be seen in the following table.

Table 5. Category of student reasoning level

\begin{tabular}{lcc}
\multicolumn{1}{c}{ Reasoning level category } & Frequency & Percentage (\%) \\
\hline Expert & 0 & $0 \%$ \\
Functional & 1 & $2 \%$ \\
Near functional & 3 & $6 \%$ \\
Subfunctional & 24 & $49 \%$ \\
Unstructured/Alternative & 21 & $43 \%$ \\
\hline
\end{tabular}

Based on table 5, 49 students who answered the ranking task exercise had different levels of reasoning. None of the 49 students of class X MIPA at SMAN 24 Bone are included in the category of Expert reasoning level, or the percentage is $0 \%$. A total of 1 student with a percentage of $2 \%$ is included in the functional level of reasoning category. A total of 3 students with a percentage of $6 \%$ were included in the category of the near functional level of reasoning. A total of 24 students with a percentage of $49 \%$ are included in the category of Subfunctional reasoning level. And as many as 21 students with a percentage of $43 \%$ included in the category of Unstructured/Alternative level of reasoning.

Based on the research data obtained, it can be seen that the level of reasoning of students is mostly in the subfunctional category, which means that students have a low level of reasoning. An indicator of the level of subfunctional reasoning is that students' explanations can correctly identify at least one relevant variable, but only the component concepts are disclosed. He does not express the relationships between important variables narratively, and student descriptions usually contain significant misapplications in terms of language, contradictions, or logical simplifications. Most of the students' reasoning levels are at the subfunctional level. This means that reasoning level one has passed but has not entered the near functional level. Students can only identify at least one relevant variable (Abdurrahman \& Efendi, 2013; Mulhayatiah et al., 2017).

In question number 1 , most students answered questions with the category of subfunctional reasoning level, which was $61 \%$. Students have been able to identify one important variable, but 
it is less precise in describing the relationship between variables. The size of the angle formed by force on the floor is inversely proportional to the work required to move the object, while the average student reveals the opposite that the angle is directly proportional to the work. This can be caused because students experience misconceptions about Work material. Likewise, in questions number 2,3 , and 8 , the level of reasoning of the students was mostly sub-functional, which were $47 \%, 57 \%$, and $47 \%$, respectively. When two concepts are presented in one question, students tend to be confused in solving the problems presented. Students can only identify one variable without describing its relationship, and the solution given is not quite right.

In question number 4, the level of unstructured/alternative reasoning appears most from the answers given by students, which is $41 \%$. In this problem, the kinetic energy possessed by all rockets is the same, so there is no need to order the images. However, students were not careful in reading the questions, so they were distracted by the speed values in each rocket image. In questions number 5, 6, 7, 9, and 10, the level of unstructured/alternative reasoning that appears most often is $47 \%, 47 \%, 45 \%, 53 \%$, and $55 \%$, respectively. Students' answers can only identify at least one variable or even reveal variables that are not related to the problem; some only repeat the instructions presented from the problem without revealing the important concepts of the problem presented.

The level of students' reasoning is still in the low category can be caused by several factors. One of the factors is the distance between giving the material, work, and energy and giving the questions quite far. Students have difficulty in answering questions because students have begun to forget the material that has been given before. Mastery of the material from students who are limited and cannot relate the concepts that have been studied previously with the problem being worked on (Coelho, 2009). As a result, students only repeat the instructions in the questions without further explanation. One of the factors that cause students to have difficulty answering questions is that the distance between giving the test and the material is quite far.

In addition, the form of the Ranking Task Exercise questions that students just got made it difficult for students to answer questions. Students are not used to working on questions in the form of questions such as the Ranking Task Exercise. Students do not understand how to answer questions, even though the researcher explains how to answer the Ranking Task Exercise questions before working on the questions. Students are not used to being given questions that are a little complicated and require a high level of problem-solving. Students who do not adequately prepare for facing the reasoning test (Ranking Task Exercise) will experience difficulties (Sternberg et al., 2019). The teacher has not given physics questions that require high reasoning skills on appropriate materials during learning so that when given the Ranking Task Exercise questions, students find it difficult to work on the questions (Wijaya, 2021).

The form of Ranking Task Exercise questions that ask students for reasons for the answers in the order given makes it difficult for students. Students find it difficult to express the reasons they think in written form. It can be seen from some students' answers who only sorted the pictures but were unable to give reasons for the given order. In addition, students do not write conclusions from the questions they work on. Students are not accustomed to giving complete conclusions on solving problems because students lack practice working on problem questions that require conclusions (Kurniasih \& Haerudin, 2019; Siregar, 2019). Meanwhile, according to the Regulation of the Director-General of Education at the Ministry of National Education Number $506 / \mathrm{C} / \mathrm{Kep} / / \mathrm{PP} / 2004$, one of the indicators of a student's reasoning ability is being able to conclude, compile evidence, provide reasons or evidence for several solutions (Musthafa et al., 2014).

The results showed that most of the students were in the subfunctional and unstructured/alternative level of reasoning categories, $6 \%$ at the near functional level, $2 \%$ at the 
functional reasoning level, and $0 \%$ or none of the students included in the expert category. This could be because students only guessed the correct answer. Students are not able to recognize all the variables in the problem and describe the relationship between variables. Students answer by describing other things that are not related to the question and do not know which formula will be used to solve the problem. This is because students do not understand the concept of work and energy. Students must begin to develop their imagination to understand the concepts contained in the material (Zainuddin et al., 2019). Students who have a low level of reasoning tend to have a low conceptual understanding. When students understand a concept, it will be easy to explain the concept in their language, and this requires reasoning in thinking as well (Abdurrahman \& Efendi, 2013; Khotimah, 2018).

Most students have difficulty in solving physics problems. These difficulties are largely due to a lack of conceptual understanding of the matter of work and energy (Hung \& Jonassen, 2006). The category of students' reasoning level is mostly at the subfunctional and unstructured/alternative reasoning level because it can only identify one variable correctly and cannot describe or describe that variable. Most of the students' answers were just guesswork and not based on scientific studies. Some students give reasons for the order chosen only by repeating the instructions for the questions, and there are those who only sort without giving reasons or explanations for the answers, and some who don't even give answers at all, which means they don't sort the pictures and don't provide explanations. When students have a good understanding of the material, students will easily explain the concept of the material even with new questions they encounter (Blumer \& Beck, 2019).

The lack of understanding of the concepts possessed by students can be caused by a lack of student interest in participating in the learning process. Learning carried out in schools is only teacher-centered so that students are less active in initial knowledge and lack motivation at the beginning of learning (Sagala et al., 2019). According to Dalyono, certain learning methods can cause students to be passive in class. This means that students are more likely to only receive lessons, and teachers are more active in the learning process. This aligns with Turmudi's opinion, which states that the teacher acts as the main driver in the teaching and learning process or what is known as teacher-centered-approach in learning. This means that students only get information from the teacher. Teaching and learning activities only take place in one direction, and students are rarely allowed to express their ideas or convey them (Burais et al., 2020; Konita et al., 2019).

The pandemic atmosphere that causes the learning process to be carried out online makes it difficult for teachers to apply appropriate learning methods in the classroom. The teacher only sends material and questions to the WhatsApp group for students to study without any reciprocity between students and teachers. Students who work on practice questions only see answers from the internet so that understanding of concepts as well as students' reasoning is less developed. The learning approach impacts the development of students' reasoning abilities (Bao et al., 2009). Reasoning ability correlates with learning achievement and improvement in concept tests, so a broader and proactive approach is needed in improving learning activities to develop students' reasoning (Bao et al., 2018). Therefore, the results of the level of reasoning that have been described in this study can be used as evaluation material by educators so that in the future, they can apply learning methods or approaches that can demand students' reasoning abilities to develop.

\section{Conclusion}

Based on the results of the research and discussion that have been described above, it can be concluded that the level of reasoning of class X MIPA students at SMAN 24 Bone in the matter of work and energy is mostly at the subfunctional and unstructured/alternative levels. If the level 
of students' reasoning on the material of effort and energy is sorted from the most to the least, they are sub-functional, unstructured/alternative, near-functional, functional, and expert. In this study, the learning method used was only conventional learning methods because the learning process was still carried out online. Therefore, further research can apply varied learning methods to obtain correlation data between RTE and the learning methods used.

\section{Acknowledgments}

The author would like to thank the supervisors and examiners for the input and suggestions given during the preparation of the thesis. In addition, the authors would like to thank the instrument validators who have provided many suggestions for improving this research instrument. Finally, the authors would like to thank the SMAN 24 Bone, who has provided the opportunity for the author to conduct research and to students who have been willing to become research subjects.

\section{References}

Abdurrahman, D., \& Efendi, R. (2013). Siswa Sma Dalam Pembelajaran Fisika Berbasis Ranking Task Exercise Peer Instruction. 1, 84-91.

Akmam, A., Anshari, R., Amir, H., Jalinus, N., \& Amran, A. (2018). Influence of Learning Strategy of Cognitive Conflict on Student Misconception in Computational Physics Course. IOP Conference Series: Materials Science and Engineering, 335(1). https://doi.org/10.1088/1757899X/335/1/012074

Bao, L., Cai, T., Koenig, K., Fang, K., Han, J., Wang, J., Liu, Q., Ding, L., Cui, L., Luo, Y., Wang, Y., Li, E., \& Wu, N. (2009). Physics: Learning and scientific reasoning. Science, 323(5914), 586-587. https://doi.org/10.1126/science.1167740

Bao, L., \& Koenig, K. (2019). Physics education research for 21st century learning. Disciplinary and Interdisciplinary Science Education Research, 1(1), 1-12. https://doi.org/10.1186/s43031-0190007-8

Bao, L., Xiao, Y., Koenig, K., \& Han, J. (2018). Validity evaluation of the Lawson classroom test of scientific reasoning. Physical Review Physics Education Research, 14(2), 20106. https://doi.org/10.1103/PhysRevPhysEducRes.14.020106

Blumer, L. S., \& Beck, C. W. (2019). Laboratory courses with guided-inquiry modules improve scientific reasoning and experimental design skills for the least-prepared undergraduate students. CBE Life Sciences Education, 18(1). https://doi.org/10.1187/cbe.18-08-0152

Burais, L., Ikhsan, M., \& Duskri, M. (2020). Peningkatan Kemampuan Penalaran Matematis Siswa melalui Model Discovery Learning. 6(2), 77-86.

Cavallo, A. M. L., Rozman, M., Blickenstaff, J., \& Walker, N. (2002). Learning, Reasoning, Motivation, and Epistemological Beliefs: Differing Approaches in College Science Courses. Journal of College Science Teaching, 3(33), 17-23.

Coelho, R. L. (2009). On the Concept of Energy: How Understanding its History can Improve Physics Teaching. Science \& Education, 18, 961-983. https://doi.org/10.1007/s11191-0079128-0

Erlina, N., Susantini, E., \& Wasis, W. (2018). Common False of Student's Scientific Reasoning in Physics Problems. Journal of Physics: Conference Series, 1108(1). https://doi.org/10.1088/1742-6596/1108/1/012016

Göhner, M., \& Krell, M. (2020). Preservice Science Teachers' Strategies in Scientific Reasoning: the Case of Modeling. Research in Science Education, Osborne 2013. https://doi.org/10.1007/s11165-020-09945-7

Handayani, G. A., Windyariani, S., Pauzi, R. Y., Biologi, P., Keguruan, F., Sukabumi, U. M., Syamsudin, J. R., No, S. H., \& Cikole, K. (2020). Profil Tingkat Penalaran Ilmiah Siswa Sekolah 
Menengah Atas Pada Materi Ekosistem (Scientific Reasoning Profile of Senior High School Students on Ecosystem Subject). 6, 176-186. https://doi.org/10.22437/bio.v4i1.5508

Hudgins, D. W. (2005). Investigation of The Effect of Rangking Task On Students Understanding of key Astronomy Topic.

Hudgins, D. W. (2007). Effectiveness of Collaborative Ranking Tasks on Student Understanding of Key Astronomy Concepts. The Astronomy Education Review, 5(1).

Hung, W., \& Jonassen, D. H. (2006). Conceptual Understanding of Causal Reasoning in Physics. International Journal of Science Education, 28(13), 1601-1621. https://doi.org/10.1080/09500690600560902

Khotimah, D., H. (2018). Profil kemampuan penalaran pada pembelajaran fisika siswa SMK Kabupaten Madiun. 25, 450-453.

Konita, M., Asikin, M., \& Noor Asih, T. S. (2019). Kemampuan Penalaran Matematis dalam Model Pembelajaran Connecting, Organizing, Reflecting, Extending (CORE). PRISMA,Prosiding Seminar Nasional Matematika, 2, 611-615.

Krell, M., Khan, S., \& Driel, J. Van. (2021). education sciences Analyzing Cognitive Demands of a Scientific Reasoning Test Using the Linear Logistic Test Model ( LLTM).

Krell, M., Mathesius, S., Driel, J. van, Vergara, C., \& Krüger, D. (2020). Assessing scientific reasoning competencies of pre-service science teachers: translating a German multiple-choice instrument into English and Spanish. International Journal of Science Education, 42(17), 28192841.

Krell, M., Redman, C., Mathesius, S., Krüger, D., \& Driel, J. van. (2018). Assessing Pre-Service Science Teachers' Scientific Reasoning Competencies. Research in Science Education, 23052329.

Kurniasih, O. Y., \& Haerudin. (2019). Analisis Kesalahan Siswa Dalam Menyelesaikan Soal Cerita Materi Limit Fungsi Trigonometri. MATHEdunesa, 8(2), 228-232.

Mahler, D., Bock, D., \& Bruckermann, T. (2021). Preservice biology teachers' scientific reasoning skills and beliefs about nature of science: how do they develop and is there a mutual relationship during the development? Education Sciences, 11(9). https://doi.org/10.3390/educsci11090558

Md, M. R. (2019). 21st Century Skill "Problem Solving": Defining the Concept. Asian Journal of Interdisciplinary Research, 2(1), 64-74. https://doi.org/10.34256/ajir1917

Mulhayatiah, D., Suhendi, H. Y., \& Oktaviani, V. (2017). Hubungan tingkat penalaran dengan hasil belajar mahasiswa melalui evaluasi teknik ranking task pada mata kuliah listrik magnet 1. WaPFi (Wahana Pendidikan Fisika), 2(1).

Musthafa, R. A., Sunardi, \& Fatahillah, A. (2014). Analisis Tingkat Kemampuan Penalaran Siswa dalam Menyelesaikan Soal Cerita Materi FPB dan KPK Kelas VII B SMP Negeri 10 Jember ( Analysis of Level Students Reasoning Ability in Resolving Problems of The Story GCD and LCM State Class VII B Junior High Scho. Jurnal Edukasi, 1(3), 1-6.

Nguyen, D. H., \& Rebello, N. S. (2011). Students' understanding and application of the area under the curve concept in physics problems. Physical Review Special Topics - Physics Education Research, 7(1), 1-17. https://doi.org/10.1103/PhysRevSTPER.7.010112

Nizam. (2016). Ringkasan hasil-hasil asesmen: belajar dari hasil UN, PISA, TIMSS, INAP. Puspendik Balitbang Kemdikbud.

O'Kuma, thomas L., Maloney, D. P., \& Hieggelke, C. J. (2004). Ranking Task Exercise in Physics: Student Edition Instructor's Guide. Upper Saddle River.

OECD. (2016). PISA 2015 result in focus paris'. OECD Publishing.

Palloan, P., \& Swandi, A. (2019). Development of learning instrument of active learning strategy integrated with computer simulation in physics teaching and learning on makassar state 
university. Journal of Physics: Conference Series, 1157(3). https://doi.org/10.1088/17426596/1157/3/032016

Purwana, U., Liliasari, \& Rusdiana, D. (2016). Profil kompetensi awal penalaran ilmiah (scientific reasoning) mahasiswa pada perkuliahan fisika sekolah. Prosiding Simposium Nasional Inovasi Dan Pembelajaran Sains, 753-756.

Rahmawati, W. (2018). Pengaruh Pendekatan pembelajaran socioscientific issues (SSI) Pada model problem solving learning terhadap kemampuan berpikir kreatif peserta didik pada materi pencemaran air. Skripsi FKIP, Pendidikan Biologi, Universitas Muhammadiyah Sukabumi.

Retnawati, H. (2006). Validitas Realibilitas \& Karakteristik Butir. Parama Publishing.

Sagala, R., Umam, R., Thahir, A., Saregar, A., \& Wardani, I. (2019). The effectiveness of stembased on gender differences: The impact of physics concept understanding. European Journal of Educational Research, 8(3), 753-761. https://doi.org/10.12973/eu-jer.8.3.753

Shen, W., Lin, Z., \& Wang, H. (2020). The application of ranking task in mechanical engineering drawing teaching strategy. 2020 IEEE Learning With MOOCS (LWMOOCS).

Shodiq, F. (2004). Penalaran, Pemecahan Masalah, dan Komunikasi Dalam Pembelajaran Matematika. PPPG Matematika.

Siregar, N. (2019). Upaya Meningkatkan Kemampuan penalaran dan komunikasi matematis siswa melalui model Pace. Pedagogy: Jurnal Pendidikan Matematika, 4(2), 58-70. https://doi.org/10.30605/pedagogy.v4i2.1443

Sternberg, R. J., Wong, C. H., \& Sternberg, K. (2019). The relation of tests of scientific reasoning to each other and to tests of general intelligence. Journal of Intelligence, 7(3). https://doi.org/10.3390/jintelligence7030020

Sukmadinata, N. S. (2014). Metode penelitian pendidikan. remaja rosdakarya.

Syafaat, E. M., Nurjannah, N., \& Werdhiana, I. K. (2014). Penerapan model pembelajaran berbasis masalah menggunakan asesmen ranking task exercise (RTE) terhadap Pemahaman konsep hukum newton. JPFT (Jurnal Pendidikan Fisika Tadulako Online), 2(1), 49. https://doi.org/10.22487/j25805924.2014.v2.i1.2769

Utami, N., Mukhini, \& Jazwinarti. (2014). Kemampuan Penalaran matematis siswa kelas XI IPA SMAN 2 Painan melalui penerapan pembelajaran think pair square. Jurnal Pendidikan Matematika, Vol 3(1), 7-12.

Wijaya, A. F. C., \& Ramalis, T. R. (2012). Collaborative ranking tasks (crt) berbantuan elearning untuk meningkatan keterampilan generik sains mahasiswa calon guru fisika. Jurnal Pendidikan Fisika Indonesia, 8(2), 144-151. https://doi.org/10.15294/jpfi.v8i2.2154

Wijaya, P. A. (2021). Mata Pelajaran Akuntansi. 1-16.

Zainuddin, Hasanah, A. R., Salam, M. A., Misbah, \& Mahtari, S. (2019). Developing the interactive multimedia in physics learning. Journal of Physics: Conference Series, 1171(1), 12-17. https://doi.org/10.1088/1742-6596/1171/1/012019

Zulfaidhah, Z., Palenewen, E., \& Hardoko, A. (2018). Needs analysis in the Problem Based Learning (PBL) Model Tools and Problems Regarding 7th Grade Students' Science Learning Outcome at SMPN 2 Bongan. BIODIK, 4(1), 48-59. https://doi.org/10.22437/bio.v4i1.5508 